\title{
Analysis of the Implementation of the Regulation of the Minister of Health Number 44 of 2016 concerning Public Health Center Management
}

\author{
Ismail Efendy ${ }^{1}$, Mappeaty Nyorong ${ }^{1}$, Himmah $^{2}$ \\ Email: arthaputrin70@gmail.com
}

${ }^{1}$ Faculty of Public Health, Helvetia Institute of Health, Medan, Indonesia

${ }^{2}$ Student of Master of Public Health Masters Program, Helvetia Institute of Health, Indonesia

\begin{abstract}
The Regulation of the Minister of Health of Indonesia Number 44 of 2016 provides guidelines for puskesmas so that they can apply the puskesmas management pattern properly and correctly. The initial data obtained by the Pegasing Health Center has not fully implemented the Regulation of the Minister of Health of the Republic of Indonesia Number 44 of 2016 concerning management guidelines. The purpose of the study was to analyze the implementation of the Minister of Health Regulation Number 44 of 2016 concerning Public Health Center management at Pegasing Public Health Center, Central Aceh Regency. The research design used qualitative methods. The informant was the head of the puskesmas, the head of administration, the head of the admin, the head of the UKP, and the head of the UKM. The data were analyzed through the stages of reduction, data presentation and drawing conclusions. The results showed that planning, mobilization and implementation, monitoring control and performance appraisal were not carried out according to the Minister of Health No. 44 of 2016, the commitment was there but not all staff knew, the management team had not been formed, there was still a lack of staff awareness regarding the Minister of Health No. 44 of 2016. The conclusion of this study is that the Minister of Health Regulation No. 44 of 2016 does not work, organizational commitment has not been socialized, there is no management team formation, lack of concern, lack of solid team work. lack of staff knowledge and employee responsibilities.
\end{abstract}

Keywords: Mobilization and Implementation, Monitoring Control, Performance Appraisal

Received : November 7, 2021

Received in Revised: December 9, 2021

Accepted: December 24, 2021

\section{Introduction}

Health development is an integral and most important part of national development. The purpose of holding health development is to increase awareness, willingness, and ability to live healthy for everyone in order to realize an optimal level of public health. The success of health development plays an important role in improving the quality and competitiveness of Indonesian people. To achieve these health development goals, various comprehensive, tiered and integrated health efforts are carried out. The Puskesmas is the person in charge of organizing health efforts for the first level (Putri et al., 2017).

The Puskesmas is a technical implementation unit of the District Health Office which is responsible for health services in its working area. The Puskesmas has the task of implementing health policies to achieve health development goals in their working areas in order to support the realization of a healthy sub-district. In order to carry out this task, the puskesmas functions 
to organize the first level Public Health Efforts (UKM) and Individual Health Efforts (UKP) in their working areas (Kemenkes, 2017).

In carrying out the function of organizing first-level SMEs in their working areas, puskesmas are authorized to plan activity plans based on the results of the analysis of public health problems and the service needs needed, carry out advocacy and socialization of health policies, mobilize the community to identify and resolve health problems at every level of community development in collaboration. with regional and related sector leaders, carry out needs planning and increase the competence of puskesmas human resources. In carrying out the function of administering the first-level UKP in its working area, the puskesmas is authorized to provide health services that prioritize promotive and preventive efforts, to provide health services that prioritize health, security, patient safety, officers, visitors and the work environment, to carry out needs planning and to increase the competence of human resources. health center human (Peraturan Menteri Kesehatan RI No 43 tahun 2019, 2019).

To carry out the duties and functions of the Puskesmas, the Puskesmas must carry out the management of the Puskesmas in an effective and efficient manner. The quality health center management cycle is a series of continuous routine activities, which are carried out in the implementation of various quality health efforts, which must be monitored regularly. Regulation of the Minister of Health of Indonesia Number 44 of 2016 provides guidelines for puskesmas so that they can implement a good and correct puskesmas management pattern effectively and efficiently. In order for health efforts to be carried out optimally, puskesmas must implement a good management process. Where the puskesmas prepares an activity plan for a five-year period, which is detailed into the puskesmas annual plan which starts from the preparation stage, situation analysis, problem formulation, preparation of proposed activity plans, preparation of activity implementation plans. Then the activities are carried out in accordance with the plans that have been prepared, after that supervision and control are carried out, where improvement and improvement efforts are also carried out, and the implementation of the evaluation of the results of the puskesmas activities is carried out through the performance appraisal phase of the puskesmas (Peraturan Menteri Kesehatan RI No 44 tahun 2016, 2016)

Based on a survey conducted in May 2021, it was found that a planning system should be implemented through several stages, starting from preparation, situation analysis, problem formulation, preparation of a draft activity proposal plan (RUK) for the following year and a draft activity implementation plan (RPK) for the current year. until the preparation of the fiveyear plan has not been fully implemented as expected based on the Regulation of the Minister of Health of the Republic of Indonesia Number 44 of 2016. At the Pegasing health center the Activity Implementation Plan (RPK) which should have been made at the beginning of the current year but in fact the Puskesmas RPK was made at the end of the year, after the activity is completed.

The system of mobilizing and implementing the program in the form of briefings on apples, the implementation of monthly activities such as mini health center workshops, mini tri monthly workshops have not been carried out optimally, where there is a lack of sense of ownership and high motivation in carrying out activities organized by the puskesmas. The monitoring, control and performance appraisal system has not been fully evaluated by the puskesmas. The performance results of the Pegasing Health Center were submitted to the Central Aceh district health office, so far there has been no feedback from the Central Aceh district health office. Performance appraisal is carried out to evaluate ongoing activities 


\section{Methods}

This study uses a qualitative method. Qualitative research is a research method that seeks to explore and understand the meanings ascribed to social or humanitarian problems by a number of individuals or groups of people (Heryana, 2019). Through qualitative descriptive research methods, researchers try to describe or describe in detail and in depth the Analysis of the Implementation of the Regulation of the Minister of Health Number 44 of 2016 concerning Public Health Center Management in Pegasing Public Health Center, Central Aceh Regency. The selection of informants in this study was carried out through a purposive sampling technique. So the samples in this study were determined, namely: the head of the Pegasing Health Center, the head of administration, the head of the administration, the head of the UKP, the head of the UKM, totaling 5 people

\section{Results and Discussion}

\section{Characteristics of Informants}

Informants in this study are the head of health center, head of business administration, chairman of admen, chairman of UKP, chairman of SMEs, numbering 5 people, as for the following characteristics of inpormas:

Table 1. Characteristics of Informant

\begin{tabular}{|l|c|l|l|c|l|}
\hline \multicolumn{1}{|c|}{ Initials } & Age & \multicolumn{1}{c|}{ Kind } & \multicolumn{1}{c|}{ Position } & Time & Education \\
\hline \multicolumn{1}{|c|}{ Code } & Year & \multicolumn{1}{c|}{ Gender } & & Work & \\
\hline Report M (01) & 48 & Man & Head of puskesmas & 23 & D4 \\
\hline Report D (02) & 44 & Woman & KTU & 13 & S1 \\
\hline Report D (03) & 50 & Man & Chairman of UKP & 11 & S1 \\
\hline Report M (04) & 35 & Woman & Chairman of SMEs & 12 & S1 \\
\hline Report W (05) & 36 & Woman & Admin Chairman & 12 & D3 \\
\hline
\end{tabular}

\section{Interview Results Overview}

Data from interviews with informants on the implementation analysis of the minister of health regulation no. 44 of 2016 on the management of health centers based on aspects of planning (P1), driving and implementation (P2), supervision, control, and performance assessment (P3), organizational commitment, health center management team, and concern inthe following information:

\section{Planning (P1)}

Based on the Planning Aspects about the management of Puskesmas obtained the following interview results:

Table 2. Matrix resume recap of informant statements about planning (P1)

\begin{tabular}{|c|c|c|c|c|c|}
\hline \multirow[t]{2}{*}{ Topic } & & & Report & & \\
\hline & 1 & 2 & 3 & 4 & 5 \\
\hline $\begin{array}{l}\text { management } \\
\text { guidelines }\end{array}$ & $\begin{array}{l}\text { At first glance } \\
\text { there is, but } \\
\text { shallow }\end{array}$ & unavailable & $\begin{array}{l}\text { unavailabl } \\
\text { e }\end{array}$ & Available & unavailable \\
\hline Explained & $\begin{array}{l}\text { Like an annual } \\
\text { work goal }\end{array}$ & & & $\begin{array}{l}\text { About the program } \\
\text { proposal, about the } \\
\text { annual work } \\
\text { program, which is }\end{array}$ & \\
\hline
\end{tabular}




\begin{tabular}{|c|c|c|c|c|c|}
\hline & & & & $\begin{array}{l}\text { taken from the } 2 \\
\text { years of program } \\
\text { performance } \\
\text { assessment results }\end{array}$ & \\
\hline $\begin{array}{l}\text { Analysis of the } \\
\text { situation }\end{array}$ & Available & Available & $\begin{array}{l}\text { Don't } \\
\text { know }\end{array}$ & Available & there is no detail \\
\hline $\begin{array}{l}\text { How to Analyze } \\
\text { the situation }\end{array}$ & $\begin{array}{l}\text { We're doing a } \\
\text { scratch. }\end{array}$ & $\begin{array}{l}\text { Don't } \\
\text { understand }\end{array}$ & $\begin{array}{l}\text { Don't } \\
\text { know }\end{array}$ & $\begin{array}{ll}\text { performance } & \\
\text { assessment } & \text { two } \\
\text { years earlier } & \end{array}$ & $\begin{array}{ll}\text { from } & \text { existing } \\
\text { data } & \end{array}$ \\
\hline $\begin{array}{l}\text { problem } \\
\text { formulation }\end{array}$ & $\begin{array}{l}\text { Data collection, } \\
\text { priority scale }\end{array}$ & $\begin{array}{l}\text { Don't } \\
\text { understand }\end{array}$ & $\begin{array}{l}\text { Don't } \\
\text { know }\end{array}$ & Mengumpulka data & $\begin{array}{l}\text { Argument } \\
\text { becomes } \\
\text { conclusion }\end{array}$ \\
\hline $\begin{array}{l}\text { When is the } \\
\text { Planned Activity }\end{array}$ & Ahir year & $\begin{array}{l}\text { Early in the } \\
\text { year }\end{array}$ & $\begin{array}{l}\text { Don't } \\
\text { know }\end{array}$ & Early in the year & Early in the year \\
\hline $\begin{array}{l}\text { What RUK study } \\
\text { made }\end{array}$ & $\begin{array}{ll}\text { based } & \text { on } \\
\text { planning } & \end{array}$ & $\begin{array}{l}\text { Data } 1 \text { year } \\
\text { back }\end{array}$ & $\begin{array}{l}\text { Don't } \\
\text { know }\end{array}$ & $\begin{array}{l}\text { Proposed activity } \\
\text { plan }\end{array}$ & Data for 2020 \\
\hline $\begin{array}{l}\text { When is RPK } \\
\text { created }\end{array}$ & January & $\begin{array}{l}\text { Early in the } \\
\text { year }\end{array}$ & $\begin{array}{l}\text { Not } \\
\text { understan } \\
\text { ding } \\
\end{array}$ & $\begin{array}{l}\text { beginning of the } \\
\text { year }\end{array}$ & $\begin{array}{l}\text { It should be the } \\
\text { beginning of the } \\
\text { year. }\end{array}$ \\
\hline RPK deal & Deal is done & Available & $\begin{array}{l}\text { Not } \\
\text { understan } \\
\text { ding }\end{array}$ & Available & There should be \\
\hline $\begin{array}{l}\text { When is the RPK } \\
\text { deal }\end{array}$ & $\begin{array}{l}\text { At the time of } \\
\text { performance } \\
\text { assessment }\end{array}$ & January & $\begin{array}{l}\text { Not } \\
\text { understan } \\
\text { ding } \\
\end{array}$ & Before the activity & Less know-how \\
\hline
\end{tabular}

In table 2. above it can be concluded that planning (P1) which started from the preparation stage where the head of the puskesmas should first explain the management guidelines, then conduct a situation analysis where in conducting a situation analysis not all informants understand how to do a situation analysis and carry out a situational analysis. formulation of the problem. The proposed plan for puskesmas activities was made at the beginning of the year, but not all of the informants understood in the study of making the proposed activity plan for activities. The activity implementation plan should have been made at the beginning of the year, but the activity implementation plan had not been made, there should have been an RPK agreement. In other words, the planning (P1) at the Pegasing Health Center which is one of the management processes has been running but not all of them are in accordance with the Regulation of the Minister of Health No. 44 of 2016 concerning management guidelines.

\section{Mobilization and Implementation (P2)}

Based on the results of the interviews, the informants' statements regarding the Movement and Implementation (P2) were obtained, as follows:

Table 3. Recap matrix of the informant's statement regarding the Movement and Implementation (P2)

\begin{tabular}{|l|l|l|l|l|l|}
\hline Topic & & & Report & & \\
\hline & \multicolumn{1}{|c|}{1} & 2 & 3 & 4 & 5 \\
\hline $\begin{array}{l}\text { First monthly mini } \\
\text { workshop }\end{array}$ & Available & Available & Available & Available & Available \\
\hline $\begin{array}{l}\text { When should the } \\
\text { first monthly mini }\end{array}$ & $\begin{array}{l}\text { At the } \\
\text { beginning of }\end{array}$ & $\begin{array}{l}\text { beginning of } \\
\text { the month }\end{array}$ & $\begin{array}{l}\text { beginning } \\
\text { of the }\end{array}$ & $\begin{array}{l}\text { beginning of } \\
\text { the year }\end{array}$ & $\begin{array}{l}\text { early } \\
\text { January }\end{array}$ \\
\hline
\end{tabular}




\begin{tabular}{|c|c|c|c|c|c|}
\hline workshop & the month, & & month & & \\
\hline $\begin{array}{l}\text { Conducted at the } \\
\text { first monthly mini } \\
\text { workshop }\end{array}$ & $\begin{array}{l}\text { about } \\
\text { strategy }\end{array}$ & $\begin{array}{l}\text { Passing } \\
\text { Grade } \\
\text { programe }\end{array}$ & $\begin{array}{l}\text { Passing } \\
\text { Grade } \\
\text { programe }\end{array}$ & $\begin{array}{l}\text { performance } \\
\text { assessment }\end{array}$ & PULL \\
\hline $\begin{array}{l}\text { Regular monthly } \\
\text { mini workshops }\end{array}$ & $\begin{array}{l}\text { Discussing } \\
\text { last month's } \\
\text { achievements }\end{array}$ & $\begin{array}{l}\text { Passing } \\
\text { Grade }\end{array}$ & $\begin{array}{l}\text { Passing } \\
\text { Grade }\end{array}$ & $\begin{array}{l}\text { Passing } \\
\text { Grade }\end{array}$ & $\begin{array}{l}\text { Passing } \\
\text { Grade }\end{array}$ \\
\hline $\begin{array}{ll}\text { First } & \text { mini- } \\
\text { tribulanan } & \\
\text { workshop } & \end{array}$ & Available & Available & Available & Available & Available \\
\hline $\begin{array}{l}\text { When was the first } \\
\text { mini tribulanan } \\
\text { workshop? }\end{array}$ & March & March & March & February & February \\
\hline $\begin{array}{l}\text { The first tri-month } \\
\text { mini workshop }\end{array}$ & $\begin{array}{l}\text { Performance } \\
\text { evaluation }\end{array}$ & $\begin{array}{l}\text { Lack of } \\
\text { understanding }\end{array}$ & $\begin{array}{l}\text { Working } \\
\text { relationship }\end{array}$ & $\begin{array}{l}\text { Activities of } \\
\text { the past year }\end{array}$ & $\begin{array}{l}\text { Passing } \\
\text { Grade } \\
\text { programe }\end{array}$ \\
\hline $\begin{array}{l}\text { Monthly mini tri } \\
\text { workshop time }\end{array}$ & Tri moonth & $\begin{array}{l}\text { Once every } \\
\text { three months, }\end{array}$ & $\begin{array}{l}\text { Less know- } \\
\text { how }\end{array}$ & $\begin{array}{l}\text { Once every } \\
\text { three } \\
\text { months, }\end{array}$ & $\begin{array}{l}\text { Once } \\
\text { every } \\
\text { three } \\
\text { months, }\end{array}$ \\
\hline $\begin{array}{lr}\text { Conducted } & \text { routine } \\
\text { tribulanan } & \text { mini } \\
\text { workshop } & \end{array}$ & $\begin{array}{l}\text { Performance } \\
\text { evaluation }\end{array}$ & $\begin{array}{l}\text { Passing } \\
\text { Grade }\end{array}$ & $\begin{array}{l}\text { Less know- } \\
\text { how }\end{array}$ & $\begin{array}{l}\text { Passing } \\
\text { Grade }\end{array}$ & $\begin{array}{l}\text { Passing } \\
\text { Grade }\end{array}$ \\
\hline Cross-sector role & Certainly & Yes & $\begin{array}{l}\text { Not } \\
\text { involved }\end{array}$ & Yes & Should \\
\hline
\end{tabular}

In table 3. above, it can be concluded that the mobilization and implementation (P2) carried out at the Pegasing Health Center starting from a monthly mini workshop was carried out, which was carried out at the beginning of the month, the draft plan for proposed activities for next year using the results of the performance assessment was discussed. one year back. Likewise with tri-monthly mini-workshops at the Pegasing Public Health Center, which should have been conducted in February for the first three-monthly mini-workshop, according to the management cycle, but the Pegasing Public Health Center held the first mini-tri-monthly workshop in March. At the time of the tri-monthly mini workshops, they discussed the performance of the Pegasing Health Center which was not achieved by asking for input from across sectors, but the participation of these cross-sectors was still lacking. The mobilization and implementation (P2) at the Pegasing Public Health Center has been running but has not been in accordance with the puskesmas management cycle based on the Minister of Health Regulation No. 44 of 2016 concerning Public Health Center management.

\section{Supervision Control and Performance Assessment (P3)}

Based on the results of interviews from informants obtained as follows:

Table 4. Recap matrix of informants' statements regarding Supervision, Control and Performance Assessment (P3)

\begin{tabular}{|l|l|l|l|l|l|}
\hline Topic & & & Report & & \\
\hline Surveillance is & 1 & 2 & 3 & 4 & 5 \\
\hline
\end{tabular}




\begin{tabular}{|c|c|c|c|c|c|}
\hline carried out & & & & & \\
\hline $\begin{array}{l}\text { Who conducts } \\
\text { surveillance }\end{array}$ & $\begin{array}{l}\text { Quality } \\
\text { team }\end{array}$ & $\begin{array}{l}\text { head of } \\
\text { puskesmas }\end{array}$ & $\begin{array}{l}\text { head of } \\
\text { puskesmas }\end{array}$ & tim audit & $\begin{array}{l}\text { head of } \\
\text { puskesmas, } \\
\text { service }\end{array}$ \\
\hline $\begin{array}{l}\text { Program holders } \\
\text { are involved }\end{array}$ & Involved & $\begin{array}{l}\text { Not } \\
\text { involved }\end{array}$ & Involving & $\begin{array}{l}\text { Yes, } \\
\text { involving }\end{array}$ & $\begin{array}{l}\text { Head of } \\
\text { puskesmas }\end{array}$ \\
\hline Control & Necessary & Necessary & Necessary & Necessary & Necessary \\
\hline How to control & $\begin{array}{l}\text { Priority } \\
\text { issues }\end{array}$ & Don't know & $\begin{array}{l}\text { Lack of } \\
\text { understanding }\end{array}$ & Audit & $\begin{array}{l}\text { Document } \\
\text { control }\end{array}$ \\
\hline $\begin{array}{l}\text { There's a } \\
\text { mismatch }\end{array}$ & Reevaluate & Don't know & $\begin{array}{l}\text { Lack of } \\
\text { understanding }\end{array}$ & Audit & $\begin{array}{l}\text { Document } \\
\text { control }\end{array}$ \\
\hline $\begin{array}{l}\text { Which is a } \\
\text { performance } \\
\text { assessment }\end{array}$ & Phc & Phc & $\begin{array}{l}\text { Head and } \\
\text { quality team }\end{array}$ & $\begin{array}{l}\text { Audit } \\
\text { Team }\end{array}$ & Admin Team \\
\hline $\begin{array}{l}\text { Submitted to the } \\
\text { health service }\end{array}$ & Avai & able & avic & $\mathrm{Av}$ & Ava \\
\hline There's verified & $\begin{array}{l}\text { There is } \\
\text { no } \\
\text { verification } \\
\text { yet. }\end{array}$ & $\begin{array}{l}\text { There is no } \\
\text { verification } \\
\text { yet. }\end{array}$ & verification & $\begin{array}{l}\text { There is no } \\
\text { verification } \\
\text { yet. }\end{array}$ & $\begin{array}{l}\text { There is no } \\
\text { verification } \\
\text { yet. }\end{array}$ \\
\hline Feedback & $\begin{array}{l}\text { There's no } \\
\text { feedback } \\
\text { yet }\end{array}$ & $\begin{array}{l}\text { There's no } \\
\text { feedback } \\
\text { yet }\end{array}$ & $\begin{array}{l}\text { Less know- } \\
\text { how }\end{array}$ & $\begin{array}{l}\text { There's no } \\
\text { feedback } \\
\text { yet }\end{array}$ & $\begin{array}{l}\text { There's no } \\
\text { feedback yet }\end{array}$ \\
\hline
\end{tabular}

In table 4 , the above can be concluded that supervision, which should be carried out by the head of the health center by involving the audit team and program manager, but in the puskesmas pegasing supervision is carried out by the head of the health center only but not routinely, in the control process has not been fully carried out even though it is deemed necessary, and performance assessment has been done even though there is no feedback from the health service. In other words, supervision, control and performance assessment (P3) has been carried out although it is not fully in accordance with what is expected under the regulation of the minister of health no. 44 of 2016.

\section{Organizational Commitment}

Based on the results of interviews from informants obtained as follows:

Table 5. Matrix Recap resume Informant statement about organizational commitment

\begin{tabular}{|l|l|l|l|l|l|}
\hline Topic & \multicolumn{1}{|c|}{1} & \multicolumn{1}{|c|}{ Report } & \\
\hline $\begin{array}{l}\text { The need for } \\
\text { organizational } \\
\text { commitment }\end{array}$ & Necessary & Necessary & Necessary & Necessary & Necessary \\
\hline $\begin{array}{l}\text { There is already an } \\
\text { organizational } \\
\text { commitment. }\end{array}$ & $\begin{array}{l}\text { It already } \\
\text { exists }\end{array}$ & don't know & $\begin{array}{l}\text { don't } \\
\text { understand }\end{array}$ & Not yet & $\begin{array}{l}\text { It already } \\
\text { exists }\end{array}$ \\
\hline Enforceable for & yes & yes & Yes & yes & yes \\
\hline $\begin{array}{l}\text { The basis } \\
\text { commitment }\end{array}$ & Easy work & collaborate & $\begin{array}{l}\text { Achieving } \\
\text { the goal }\end{array}$ & Consequent \\
\hline
\end{tabular}




\begin{tabular}{|l|l|l|l|l|l|}
\hline Responsible and & $\begin{array}{l}\text { Will be } \\
\text { responsible }\end{array}$ & $\begin{array}{l}\text { Certainly } \\
\text { responsible }\end{array}$ & Certainly & yes & $\begin{array}{l}\text { Must be } \\
\text { responsible }\end{array}$ \\
\hline Consequent & Answer & Answer & & & Answer \\
\hline
\end{tabular}

In table 5.above it can be concluded that the organization's commitment in the pegasing health center needs to be made, and the organization's commitment in the pegasing health center already exists, but not all employees know that the organizational commitment has been made, where the basis for the establishment of a committee so that all staff can be responsible.

\section{Puskesmas Management Team}

In Table 6, the results of informant interviews with the management team no longer think for themselves there is a team for

Table 6. Matrix Recap Resumes Informant's Statement About Health Center Management Team

\begin{tabular}{|l|l|l|l|l|l|}
\hline Topic & \multicolumn{2}{|c|}{1} & \multicolumn{1}{c|}{2} & \multicolumn{1}{c|}{ Report } & \multicolumn{1}{c|}{5} \\
\hline $\begin{array}{l}\text { Formation of } \\
\text { a } \\
\text { management } \\
\text { team }\end{array}$ & Not yet & Not yet & $\begin{array}{l}\text { Lack of } \\
\text { understanding }\end{array}$ & Not yet & Not yet \\
\hline $\begin{array}{l}\text { Why hasn't it } \\
\text { been formed } \\
\text { yet? }\end{array}$ & $\begin{array}{l}\text { Lack of } \\
\text { understanding }\end{array}$ & $\begin{array}{l}\text { lack of } \\
\text { understanding }\end{array}$ & $\begin{array}{l}\text { Lack of } \\
\text { understanding }\end{array}$ & $\begin{array}{l}\text { Less } \\
\text { know- } \\
\text { how }\end{array}$ & $\begin{array}{l}\text { Not too } \\
\text { understanding }\end{array}$ \\
\hline $\begin{array}{l}\text { Needs to be } \\
\text { in shape }\end{array}$ & Necessary & Necessary & Necessary & Necessary & Necessary \\
\hline $\begin{array}{l}\text { Management } \\
\text { can run Nut Perfect }\end{array}$ & Not Perfect & Not Perfect & Do not & Directionless \\
\hline $\begin{array}{l}\text { The work } \\
\text { will be light } \\
\text { if the } \\
\text { management } \\
\text { team is there. }\end{array}$ & Very clear & Yes & Yes & Yes & Certainly \\
\hline
\end{tabular}

In table 6 , the above can be concluded that in the pegasing health center so far the management team has not been formed, where informants do not understand about the management team. So far the management of puskesmas runs even though it has not been in the management team but the management of the puskesmas is not running perfectly. Puskesmas pegasing considers it necessary in the form of a puskesmas management team to facilitate in carrying out puskesmas management.

\section{Concern}

In Table 7, the results of the interview above, the informant said that not all program holders provide achievements at the time of lokmin tribulanan

Table 6. Matrix Recap Resumes Informant's Statements About Concern

\begin{tabular}{|l|l|l|l|l|l|}
\hline Topic & & & Report & & \\
\hline & 1 & 2 & 3 & 4 & 5 \\
\hline Application & not yet & Not all & Lack of & Some & Some \\
\hline
\end{tabular}




\begin{tabular}{|l|l|l|l|l|l|}
\hline On time & Not all & not yet & $\begin{array}{l}\text { Less know- } \\
\text { how }\end{array}$ & some & some \\
\hline $\begin{array}{l}\text { Proposed Activity } \\
\text { Plan }\end{array}$ & Available & $\begin{array}{l}\text { RUK } \\
\text { available }\end{array}$ & $\begin{array}{l}\text { Don't } \\
\text { understand }\end{array}$ & $\begin{array}{l}\text { RUK } \\
\text { available }\end{array}$ & RUK available \\
\hline $\begin{array}{l}\text { Activity } \\
\text { Implementation } \\
\text { Plan }\end{array}$ & Available & $\begin{array}{l}\text { RPK } \\
\text { tidak }\end{array}$ & $\begin{array}{l}\text { Don't } \\
\text { understand }\end{array}$ & $\begin{array}{l}\text { Partial } \\
\text { RPK }\end{array}$ & Not RPK \\
\hline $\begin{array}{l}\text { Looking for the } \\
\text { cause of the } \\
\text { problem }\end{array}$ & Yes & Yes & Yes & Yes & Usually so \\
\hline $\begin{array}{l}\text { Follow-up in } \\
\text { Presence } \\
\text { apples }\end{array}$ & Mandatory & Some & should & Some & Do not \\
\hline $\begin{array}{l}\text { Presence } \\
\text { monthly lokmin }\end{array}$ & Do not & Some & should & Some & Do not \\
\hline $\begin{array}{l}\text { Giving } \\
\text { achievements to } \\
\text { lokmin }\end{array}$ & must & Not all & Some & Some & Not all \\
\hline $\begin{array}{l}\text { Giving } \\
\text { achievements to } \\
\text { lintor }\end{array}$ & must & Some & Some & Some & Some \\
\hline
\end{tabular}

In table 7. The above can be concluded that in the pegasing health center for the level of concern is still less this is seen from only some programs that care in the creation of the Program Activity Implementation Plan which will be RPK puskesmas for one year. for care in apples and monthly mini workshops puskesmas are still lacking. Likewise, in the provision of achievements in monthly mini workshops and mini tri monthly workshops puskesmas.

\section{Implementation Analysis of Permenkes No. 44 of 2016 on the management of Puskesmas in puskesmas pegasing Central Aceh Regency based on planning (P1)}

The results showed that planning (P1) which started from the preparation stage where the head of the puskesmas should first explain the management guidelines, then conduct a situation analysis where not all informants understood how to analyze the situation and formulate the problem in conducting a situation analysis. The proposed plan for puskesmas activities was made at the beginning of the year but not all of the informants understood in the study of making the proposed activity plan for activities. The implementation plan for the activity should have been made at the beginning of the year, but the implementation plan for the activity has not been made, there should be an agreement on the implementation plan Activity. In other words, the planning (P1) at the Pegasing Health Center which is one of the management processes has been running but not all of them are in accordance with the Regulation of the Minister of Health No. 44 of 2016 concerning management guidelines.

As we know planning is one of the most important functions in management, because planning will determine other management functions, especially decision making. The planning function is the basic foundation of the overall management function. Without planning, the implementation of activities will not run well. 
In accordance with research conducted by Niah (2015) shows that planning has a dominant effect on the performance of puskesmas management. Where to improve the performance of puskesmas management it is necessary to plan a good puskesmas level.

According to Handoko, in Arifin (2016) planning is to give answers to the questions what (what), who (who), when (when), where (where), why (why) and how (how). In other words, planning is the function of a manager related to the selection of a set of activities and the determination of goals, policies and programs carried out (Arifin et al., 2016).

Planning can be prepared through proper identification of problems based on accurate data, and obtained in the right way and at the right time, so that it can direct health efforts carried out by puskesmas in achieving goals and objectives (Peraturan Menteri Kesehatan RI No 44 tahun 2016, 2016).

Puskesmas planning includes the preparation of a five-year plan and an annual puskesmas plan, in which the planning is carried out in several stages. At the preparation stage, the puskesmas staff who are involved in the process of preparing the five-year plan and the puskesmas annual plan, should have the same views and knowledge, by forming a puskesmas management team, with an explanation of the puskesmas management guidelines. By studying the five-year plan of the district health office, minimum service standards (SPM) at the district level, targets agreed with the district health office, general guidelines for the Healthy Indonesia program with a Family Approach (PISPK) which the team considers necessary to know in the preparation of puskesmas planning.

The situation analysis phase is carried out to obtain information about the situation and identify health problems faced by the puskesmas, in order to formulate service needs and fulfill community expectations.

The problem formulation stage is carried out after the problem is carried out after the results of data analysis. By identifying the problem, setting the order of priority of the problem with the agreement of the team, or by using a screening technique, then the root cause of the problem is searched using a fishbone diagram or a problem tree. Furthermore, the determination of how to solve the problem can be done by brainstorming.

According to the researcher's assumption that the planning activities (P1) at the Pegasing Public Health Center have not been going well, this is because the Minister of Health Regulation No. 44 of 2016 regarding management guidelines has not been implemented where this guideline is one of the references to make it easier for us to carry out the management of the Public Health Center, However, the Pegasing Health Center has not fully implemented planning based on these guidelines, this happens because there is no puskesmas management team, so the planning process is not optimal, besides that planning has not been maximally implemented because data and information management at the Pegasing Health Center is still lacking, so that it affects planning in the Pegasing Health Center. In addition to that, the head of the Pegasing Public Health Center, who is now the new Head of the Puskesmas, does not yet understand the management of the Puskesmas.

Analysis of the Implementation of the Minister of Health Regulation Number 44 of 2016 concerning the management of the Puskesmas in Pesasing Public Health Center, Central Aceh Regency based on Mobilization and Implementation (P2)

The results showed that the mobilization and implementation (P2) carried out at the Pegasing Health Center starting from a monthly mini workshop was carried out, which was carried out 
at the beginning of the month, the draft plan for proposed activities for next year using the results of the performance assessment one year ago. Likewise with mini tri-monthly workshops, at the Pegasing Health Center there were conducted, which should have been the first mini-tri-monthly workshop at the Puskesmas in February, according to the management cycle, but the Pegasing Public Health Center held the first mini-tri-monthly workshop in March and the mini-tri-monthly workshop. routine until now has not been implemented.

At the time of the tri-monthly mini workshops, they discussed the performance of the Pegasing Health Center which was not achieved by asking for input from across sectors, but the participation of these cross-sectors was still lacking. The mobilization and implementation (P2) at the Pegasing Health Center has been running but has not been in accordance with the puskesmas management cycle based on the Minister of Health Regulation No. 44 of 2016

In accordance with research conducted by Tarumaseles (2020) shows that there is an influence of planning, supervision, control and assessment on the quality of puskesmas services

Mobilization and implementation are follow-up activities from the Activity Implementation Plan (RPK) which can be carried out through official meetings, briefings at employee meetings, implementing program activities based on the schedule contained in the monthly RPK and through mini-workshops at the puskesmas (Peraturan Menteri Kesehatan RI No 44 tahun 2016, 2016)

George R Terry in Sulistyawati (2018), actuating is an effort to move group members so that they are willing and trying to achieve organizational goals and organizational goals, because these members also want to achieve goals (Sulistyawati et al., 2018)

The mobilization and implementation of the puskesmas includes the first mini-monthly workshop, regular mini-monthly workshop, the first tri-monthly mini-workshop and routine mini-trimonthly workshop. The first monthly mini-workshop was a team-building workshop, which was held to organize and implement the Puskesmas RPK. The regular monthly miniworkshop is a continuation of the first monthly mini-workshop, which is held by the district to monitor the implementation of puskesmas activities, which is carried out every month. The first tri-monthly mini-workshop is also a team-building which is held in the context of organizing for the implementation of cross-sectoral activity plans in the health sector. Regular tri-monthly mini-workshops are a follow-up to the previous cross-sectoral collaboration (Peraturan Menteri Kesehatan RI No 44 tahun 2016, 2016)

According to the researcher's assumption that the Mobilization and Implementation (P2) activities at the Pegasing Health Center have not been carried out in accordance with the Regulation of the Minister of Health No. 44 of 2016 concerning management guidelines, this occurs because the head of the Puskesmas has not been able to direct subordinates in carrying out activities based on the Permeskes. This happens because the head of the puskesmas has not attended the puskesmas management training, which is one of the requirements to become the head of the puskesmas, so the head of the puskesmas is expected to be able to direct his subordinates in carrying out the management of the puskesmas.

Analysis of the Implementation of the Minister of Health Regulation Number 44 of 2016 concerning the management of the Puskesmas in Pesasing Public Health Center, Central Aceh Regency based on Supervision, Control, and Performance Assessment (P3)

The results showed that supervision was carried out by the head of the puskesmas but not routinely, in the control process it had not been fully implemented even though it was deemed 
necessary, and performance appraisals had been carried out even though there was no feedback. In other words, supervision, control and performance appraisal (P3) have been carried out even though they are not fully as expected based on the Minister of Health Regulation No. 44 of 2016. Supervision and control need to be carried out so that the performance targets of each activity can be achieved optimally,

In accordance with research conducted by Ayu Prasetyowati (2017), it shows that showing controlling $(\mathrm{p}=0.016)$ has an effect on improving the performance of puskesmas

In order for the output target of each puskesmas activity to be achieved optimally, it is necessary to carry out supervision and control. Supervision can be carried out internally and externally. Internal supervision is supervision carried out by the puskesmas itself. While external supervision is supervision carried out by outside agencies, such as the district health office or other agencies or the community (Peraturan Menteri Kesehatan RI No 44 tahun 2016, 2016)

According to Siagian, in ulfatiningsih (2019), supervision is an organic function of management which is the process of observing all organizational activities in order to better ensure that all work being carried out is in accordance with a predetermined plan (Ulfatiningsih, 2019).

Control is a process of monitoring and directing the achievement of organizational goals. Measurement and comparison of the results achieved with the results that should be achieved. Control is carried out in the form of management, namely: manuals, standard criteria, norms, instructions, and other procedures. Control is a management function where the leader is at the center of monitoring and directing activities (Sugiyanto, 2016).

Control is a series of activities to ensure the conformity of the implementation of activities with the plans that have been previously set, by comparing the current achievements with the targets that have been previously set. If there is a discrepancy, improvement efforts must be made, which are carried out in stages, both by the district health office, the head of the puskesmas, and the person in charge of the program (Peraturan Menteri Kesehatan RI No 44 tahun 2016, 2016)

Community health center performance appraisal is an objective and systematic process of collecting, analyzing and using information to determine how effective and efficient puskesmas services are, as well as the targets achieved as an assessment of puskesmas performance results. The implementation of the performance appraisal is carried out by the puskesmas, where the results of the performance appraisal are verified by the district health office, including the results of achieving the implementation of health services. Community health efforts, individual health efforts and puskesmas management. performance is sufficient, and the level of performance is less (Peraturan Menteri Kesehatan RI No 44 tahun 2016, 2016)

According to the researcher's assumption that the supervision, control, and performance appraisal activities at the Pegasing Public Health Center have not run optimally in accordance with the Regulation of the Minister of Health No. 44 of 2016 concerning management guidelines due to the lack of knowledge of the head of the puskesmas in conducting supervision and control, and should involve program holders. 


\section{Analysis of the Implementation of the Minister of Health Regulation Number 44 of 2016 concerning the management of the Puskesmas in Pesasing Public Health Center, Central Aceh Regency based on Organizational Commitment}

The results show that organizational commitment at the Pegasing Health Center already exists, but not all employees know that organizational commitment has been made, in which the basis for the formation of a committee so that all staff can be responsible.

According to research conducted by Sulistyawati (2018), to improve the implementation of Puskesmas management, it can be done by raising commitments from leaders and all employees, leaders make policies to make joint commitments, improve coordination and cooperation from leaders and employees. Commitment is one of the important factors for achieving organizational goals (Sulistyawati et al., 2018)

Commitment is a promise (agreement/contract) to do something. Promises to ourselves and to others are reflected in our actions. Commitment is a complete acknowledgment, as a true attitude that comes from the character that comes out from within a person (Mulyajansih, 2019)

Once a person is committed, whatever happens he must be responsible, he must be thorough, he must be honest, he must keep his promise and he must do what is his obligation (Wahyudi, 2020)

Organizational commitment is all the feelings and attitudes of employees towards everything related to the organization where they work including their work, which can be seen from the willingness to maintain the organization or determination to achieve organizational goals, active involvement in working on organizational goals and loyal loyalty. high in the organization. This form of partisanship and concern for employees can be done in various ways such as being involved in organizational activities, reducing time wasting at work and reducing the possibility of leaving the work environment (Mulyajansih, 2019).

According to the researcher's assumption that organizational commitment is not yet known by all staff, because the making of the commitment does not involve all staff. Besides that, at the time of raising the committee, nothing was socialized beforehand, what was the raising of the commitment made for.

Analysis of the Implementation of the Minister of Health Regulation Number 44 of 2016 concerning the management of the Puskesmas in Pesasing Public Health Center, Central Aceh Regency based on the Puskesmas Management Team

The results showed that at the Pegasing Health Center a management team had not yet been formed, where the informants did not understand the management team. So far, the management of the puskesmas is running, although a management team has not yet been formed, but the management of the puskesmas is not running perfectly. The Pegasing Health Center considers it necessary to form a puskesmas management team to facilitate the management of the puskesmas. To ensure a quality health center management cycle, a puskesmas management team is needed, which is able to work well and professionally.

To ensure that the quality health center management cycle runs effectively and efficiently, a puskesmas management team is established which can also function as the person in charge of quality management at the puskesmas. The puskesmas management team consists of the person in charge of health efforts at the puskesmas and is fully supported by their respective implementing ranks. This management team is also responsible for achieving the performance targets of the puskesmas, through the implementation of quality health efforts. The puskesmas 
management team must be able to work well and professionally under the coordination and supervision of the puskesmas head who carries out his leadership function properly and appropriately according to the situation and conditions (Peraturan Menteri Kesehatan RI No 44 tahun 2016, 2016). The puskesmas management team has the task of preparing the puskesmas level planning, so this team can be called the puskesmas level planning team (Dachi, 2018).

Resource and quality management is an integrated health center management system that is not separated from one another, which must be fully controlled by the puskesmas management team under the leadership of the puskesmas head in an effort to realize quality health center performance, support the achievement of the goals and objectives of implementing health efforts at the puskesmas, in order to overcome the health problems faced by the community in their work area. The management of the puskesmas will integrate all existing management (resources, programs, community empowerment, puskesmas information systems and quality) in solving priority health problems in their working areas (Peraturan Menteri Kesehatan RI No 44 tahun 2016, 2016).

It is necessary to establish a puskesmas management team to ensure that the quality health center management cycle runs effectively and efficiently. The puskesmas management team can also function as the person in charge of quality management at the puskesmas. the team consists of the person in charge of health efforts at the puskesmas and is fully supported by their respective implementing ranks (Kemenkes, 2017).

According to the researcher's assumption, the puskesmas management team has not yet been formed at the Pegasing Health Center because they do not understand the contents of the Minister of Health Regulation No. 44 of 2016 concerning management guidelines, in addition to the lack of knowledge from the head of the puskesmas and staff about the management of the puskesmas so that a management team is not formed which is one of the directives in the Permenkes.

\section{Analysis of the Implementation of the Minister of Health Regulation Number 44 of 2016 concerning the management of the Puskesmas in Pesasing Public Health Center, Central Aceh Regency based on Concern}

The results of the research show that at the Pegasing Health Center the level of care is still lacking, it can be seen from only some programs that care in making the Program Implementation Plan which will become the Community Health Center's RPK for one year. there is still a lack of awareness in apple and monthly mini-workshops at the puskesmas. Likewise in providing achievements in mini-monthly workshops and tri-monthly miniworkshops of puskesmas. In fact, the achievements of the program really need to be conveyed in mini-monthly workshops and mini-tri-monthly workshops of the puskesmas to find out the achievements of the puskesmas that are experiencing problems, so that they can be followed up.

In accordance with research conducted by Steffany (2017), the staff's lack of discipline at work is due to the lack of concern and awareness of puskesmas employees at work. The attitude of someone who does not want to care about the social conditions of the environment even though he knows what is going on in his environment. 
Caring is a form of real action taken by someone in responding to a problem. In the Big Indonesian Dictionary, caring is participation, namely participation. The word care has various meanings, therefore caring is concerned as a task, role, and relationship. The word caring is also related to personal, emotional and needs (Eprints.Uny.Ac.Id/66632/3/BaB\%/2011 Pdf Yaumi (2014), n.d.).

Caring according to Sugono in the Indonesian Ministry of Health (2017) is to heed, pay attention and ignore. The value of caring is very important for an employee in life in the world of work and in society (Kemenkes, 2017).

Caring, which is related to what is in the heart and moral ethical considerations when dealing with other people. Someone who has a caring attitude, always uses the subtlety of mind and feelings so that they can empathize with the joy or pain experienced by others. caring is the heart of ethics, and ethics in making decisions. It is said that the heart of ethics is because giving care to others is the best way to be ethical, even though it may be hindered in the small heart to fully give attention (Eprints.Uny.Ac.Id/66632/3/BaB\%/2011 Pdf Yaumi (2014), n.d.).

Caring is a basic value and an attitude of paying attention and acting proactively about the conditions or circumstances around us. Caring is an attitude of taking sides with us to involve ourselves in problems, circumstances or conditions that occur around us. Caring people are those who are called to do something in order to inspire, change, and be kind to the environment around them. When someone sees a certain situation, he will be moved to take some action (Petir-Ronkop.Desa.Id/Frist/Artikel/573-Empati-Simpati-Dan Peduli, n.d.)

According to the researcher's assumption, the lack of awareness of the puskesmas staff towards the regulation of the minister of health no 44 of 2016, was due to the staff's ignorance of the stages of making a situation analysis, problem formulation, making RUK, and making RPK

\section{Conclusion}

Based on the research that has been done, it can be concluded that planning (P1), mobilization and implementation (P2), supervision, control and performance appraisal (P3) at the Pegasing Health Center which is one of the management processes has not been running in accordance with the Regulation of the Minister of Health No. 44 In 2016, organizational commitment at the Pegasing Health Center already existed, but not all employees knew that organizational commitment had to be implemented in accordance with existing regulations and a management team had not been formed at the Pegasing Public Health Center so that supervision did not go well.

\section{References}

Arifin, S., Rahman, F., Wulandari, A., \& Anhar, V. Y. (2016). Buku Dasar-dasar Manajemen Kesehatan. Pustaka Benua.

Dachi, R. A. (2018). Manajemen Puskesmas. 1-94. eprints.uny.ac.id/66632/3/BaB\%/2011 pdf yaumi (2014). (n.d.).

Heryana, A. (2019). Buku Ajar Metodologi Penelitian pavailable Kesehatan Masyarakat. In Bahan Ajar Keperawatan Gigi (Issue June).

Kemenkes. (2017). Modul Pelatihan Manajemen Puskesmas. Pusat Pelatihan SDMK Bavailablen PPSDM Kesehatan.

Mulyajansih, R. (2019). Pengaruh Komitmen Organisasi Dan Etos Kerja Islam Terhavailablep Kinerja Karyawan (Studi pavailable Bank Pembiayaan Rakyat Syariah Metro 


\section{Mavailableni Kantor Pusat).}

Peraturan Menteri Kesehatan RI No 43 tahun 2019. (2019). Peraturan Menteri Kesehatan RI No 43 tahun 2019 tentang Puskesmas. Peraturan Menteri Kesehatan RI No 43 Tahun 2019 Tentang Puskesmas, Nomor 65(879), 2004-2006.

Peraturan Menteri Kesehatan RI No 44 tahun 2016. (2016). peraturan Menteri Kesehatan RI No 44 tahun 2016 tentang pedoman manajemen puskesmas. Peraturan Menteri Kesehatan RI No 44 Tahun 2016. petir-ronkop.desa.id/frist/artikel/573-empatisimpati-dan peduli. (n.d.).

Putri, W. C. W. S., Yuliyatni, P. C. D., Aryani, P., Sari, K. A. K., \& Sawitri, A. A. S. (2017). Dasar-dasar Pusat Kesehatan Masyarakat (Puskesmas). Modul Pembekalan Manajemendan Program Puskesmas, 14.

Sugiyanto, E. (2016). Pengendalian Dalam Organisasi. In Journal of Chemical Information and Modeling (Vol. 53, Issue 9). LPU-Unas.

Sulistyawati, D., Manajemen, M., Widya, S., \& Yogyakarta, W. (2018). evaluasi implementasi manajemen puskesmas di UPTD Puskesmas Pejagoan Kabupaten Kebumen.

Ulfatiningsih. (2019). Evaluasi manajemen puskesmas di puskesmas klirong I Kecamatan Klirong kabupaten kebumen.

Wahyudi. (2020). komitmen organisasi. unpam press. 